Tamara Rajić ${ }^{1}$

Ivan Nikolić ${ }^{2}$

Isidora Milošević ${ }^{3}$
JEL: M31, C51

DOI: $10.5937 /$ industrija44-10741

UDC: 659.127 .6

005.346

Original Scientific Paper

\title{
The Antecedents of SMEs' Customer Loyalty: Examining the role of Service Quality, Satisfaction and Trust
}

\author{
Article history: \\ Received: 19 April 2016 \\ Sent for revision: 6 June 2016 \\ Received in revised form: 3 August 2016 \\ Accepted: 6 August 2016 \\ Available online: 8 October 2016
}

Abstract: This study aims to propose and empirically examine a model of SMEs' customer loyalty. The study builds upon previously established relationships among service quality, customer satisfaction and loyalty and enhances previous conceptualizations by incorporating the construct of trust. Hypothesized relationships have been simultaneously examined on a sample of SMEs' customers, by means of structural equation modelling (SEM) using maximum likelihood as the method of parameter estimation. Results of the study indicate customer satisfaction as the main direct determinant of customer loyalty, followed by trust, whereas the impact of service quality is mediated via satisfaction and trust. Implications of the study have been discussed and directions for future research are highlighted.

Key words: service quality, satisfaction, trust, customer loyalty, SMEs, structural equation modelling

\section{Determinante lojalnosti potrošača malih i srednjih preduzeća: ispitivanje značaja kvaliteta usluga, satisfakcije i poverenja}

Apstrakt: Cilj ovog rada je predložiti $i$ empirijski ispitati model lojalnosti potrošača malih i srednjih preduzeća (MSP). Istraživanje se zasniva na odnosima između kvaliteta usluga, satisfakcije i lojalnosti koji su ustanovljeni

\footnotetext{
${ }^{1}$ Economics Institute a.d., Belgrade, tamara.rajic@ecinst.org.rs

${ }^{2}$ Economics Institute a.d. Belgrade

${ }^{3}$ University of Belgrade, Technical faculty in Bor 
Rajić T. et al.: The Antecedents of SMEs' Customer Loyalty: Examining the role...

u prethodnim istraživanjima $i$ predstavlja proširenje postojećih modela uključivanjem koncepta poverenje. Odnosi između latentnih koncepata ispitivani su simultano, na uzorku potrošača malih i srednjih preduzeća, primenom modelovanja pomoću strukturnih jednačina (SEM), korišćenjem metoda maksimalne verodostojnosti za ocenu parametara modela. Rezultati istraživanja ukazuju na to da je satisfakcija ključna direktna determinanta lojalnosti, a sledi je poverenje, dok je uticaj kvaliteta usluga posredovan putem satisfakcije i poverenja. $U$ radu su razmotrene implikacije istraživanja $i$ istaknute smernice za buduća istraživanja.

Ključne reči: kvalitet usluga, satisfakcija, poverenje, lojalnost potrošača, $M S P$, modelovanje pomoću strukturnih jednačina

\section{Introduction}

Over previous years the construct of customer loyalty has gained much attention among practitioners and scholars alike. Having loyal customer base represents a significant competitive advantage for a company. Loyal customers tend to buy more over time, pay price premiums, spread positive word-of-mouth about a company and therefore bring in new customers (Reichheld, 2003). Serving loyal customers leads to revenue growth, which is a result of repeat purchases and referrals, decline of costs, as a consequence of serving more experienced customers and reduction of failure costs, and employee retention and loyalty, as a consequence of positive impact of customer loyalty on employees' job satisfaction and loyalty (Reichheld, 1993). Loyal customers are easier to reach and they also act as enthusiastic advocates for a company (Harris \& Goode, 2004). Repeat purchase is frequently emphasized as the main benefit of having loyal customer base. However, according to Reichheld (2003) true loyalty is much more than repeat purchases, as repeat purchases may stem from lack of alternatives, customer inertia or indifference, high exit barriers erected by a company or circumstances. This notion is also supported by Dick and Basu (1994) who suggest that "both a favorable attitude that is high compared to potential alternatives and repeated patronage are required for loyalty" (p.100). Past research provides evidence of a powerful impact of customer retention on a company's bottom line. Reducing customer defections by just 5 points generated $85 \%$ more profits in the case of one bank, profit rise of $50 \%$ and $30 \%$ in an insurance brokerage and auto-service chain, respectively (Reichheld, 1990). Therefore, understanding cultivation of true loyalty is a key to a company's long-term profitability (Chiou \& Droge, 2006).

Literature review provides evidence of a number of influential factors that add to the development of customer loyalty. Service quality and customer 
Rajić T. et al.: The Antecedents of SMEs' Customer Loyalty: Examining the role...

satisfaction have gained the status of the most frequently examined determinants of customer loyalty. Although building trustworthy image may enhance customer loyalty (Chiou \& Droge, 2006), heretofore the construct of trust, as a determinant of loyalty, has not received equal scholarly attention.

Although there exists a large body of literature including models of customer loyalty, most of the past studies were conducted in the US and other developed markets, whereas emerging economies have largely been neglected. Moreover, rarely were previous studies focused on examination of loyalty models in the context of small and medium-sized enterprises (SMEs), or at least the context of SMEs was not emphasized in particular as studies' setting. However, probing deeper into the determinants of customer loyalty is especially relevant in the context of SMEs, as these enterprises are generally considered as the backbone of European economy and the main drivers of economic growth and new job creation. According to Eurostat's study (2011) with a special feature on SMEs, these enterprises account for $99.8 \%$ of the total number of enterprises active in the EU-27's non-financial business economy and they created two out of every three jobs $(66.7 \%)$ and $58.6 \%$ of value-added of the non-financial business economy. Small and medium-sized enterprises represent important business entities of Serbian economy, as well. They account for $99.4 \%$ of the total number of enterprises in Serbian non-financial business economy, employ $59.1 \%$ of workforce, generate $59.4 \%$ of turnover and $48 \%$ of value-added of the non-financial business economy (RZS, Strukturne poslovne statistike, 2014). In terms of number of enterprises, leading position is occupied by the sector of wholesale and retail trade, repair of motor vehicles and motorcycles $(38.2 \%)$, which is followed by mining and quarrying (19.1\%) and professional, scientific and technical activities (12.9\%). However, in terms of performances, SMEs in Serbia, lag behind their EU counterparts. One study's findings also indicate that strategic planning is not widespread among Serbian SMEs (Mamula \& Popović-Pantić). An additional drawback of Serbian SMEs is their average size, as they employ approximately 2.4 persons, whereas European average is 4.2 (Vlada Republike Srbije, 2014). Improvements in competitive position of Serbian SMEs in a prerequisite for economic growth and competitiveness of Serbian economy. Market knowledge, including information on customers' needs and consumer behavior, is indispensable for enhancement of competitiveness of Serbian SMEs.

Therefore, this study aims to probe deeper into the determinants of customer loyalty and their relative importance in building a loyal customer base. The study has been performed on a sample of SMEs' customers in the context of Serbian retailing, as a segment of leading sector of Serbian non-financial business economy, which is expected to take the role of the main driver of Serbian economic growth and development (Lovreta, 2008). By focusing on customer loyalty determinants in thus far largely under-researched context of 
Rajić T. et al.: The Antecedents of SMEs' Customer Loyalty: Examining the role...

an emerging economy, this study aims to add to the growing body of knowledge in Services Marketing literature.

The remainder of the paper is structured as follows. The following section provides literature review of the main determinants of customer loyalty and their hypothesized relationships. Methodology is explained subsequently, which is followed by the results of the study and their discussion. Last section deals with the summary of the main study's findings.

\section{Literature review and hypotheses}

\subsection{Service Quality}

The construct of service quality has gained the status of the most extensively studied research area in Services Marketing literature to date. Theory on service quality has evolved around two schools of thought, European, whose founding father is Christian Grönroos, and North-American, whose founders are Parasuraman, Zeithaml and Berry. Both schools of thought agree on a multi-dimensional nature of service quality construct. However, according to the model of Grönroos, which was first presented in English in 1982, service quality as perceived by customers has two dimensions, a technical or outcome-related dimension, and a functional or process-related dimension. Whereas technical dimension relates to what customers receive in their interactions with a service company, functional quality refers to how a customer receives the service and experiences the simultaneity of service production and consumption (Grönroos, 2000). According to Parasuraman et al. (1985, p.42-43) "service quality involves more than outcome, it also includes the manner in which the service is delivered“. Nevertheless, the aforementioned authors in their extensive probing into the quality of services from customers' perspective focused exclusively on process-related aspect of service delivery. Their research resulted in a 22 -item scale for service quality measurement, called SERVQUAL, which is designed to be applicable across a broad spectrum of service industries (Parasuraman et al., 1988). However, applicability of this generic instrument has been questioned by a number of authors, supporters of the idea that service quality measurement instruments developed in one market should not be directly transposed in other markets, without taking into account variation in cultural, socio-economic and environmental factors (Greenland et al., 2006). Subsequently this led to a number of modifications of SERVQUAL instrument, in order to adjust it to different socio-economic and cultural settings (Yieh et al., 2007; Kuo et al., 2011; Hussain et al., 2015). Although North-American school has gained more attention in Service Marketing literature, a consensus has not evolved yet as to which, if either, of these perspectives represent a more appropriate 
Rajić T. et al.: The Antecedents of SMEs' Customer Loyalty: Examining the role...

perspective of service quality. Literature review provides evidence of several attempts to reconcile these two conceptualizations. McDougall and Levesque (2000) differentiate between core service quality (what is delivered) and relational service quality (how it is delivered) and in the context of four types of services, dental services, auto service, restaurant and hairstylist services, provide evidence of significant impact of both quality dimensions on customer satisfaction. According to Chiou and Droge (2006) customers' perceptions of overall service quality are shaped by facility service quality, which is related to aspects such as modern equipment, and interactive service quality, which is influenced by promptness and kindness of front-line service personnel and as such is regarded as the primary aspect of service quality construct in Services Marketing literature. In the context of high-involvement luxury cosmetics market these authors also provided empirical support for the direct relatedness of interactive service quality to trust. The same approach of reconciliating these two perspectives of service quality was adopted in this study, too. Qualitative study was performed first, with the aim of generating SERVQUAL-type items relating to both core and interactive service quality.

Review of relevant literature provides evidence of a number of positive consequences of service quality. Durvasula et al. (2005) argue that improved service quality leads to higher customer satisfaction. This notion was supported by Choi et al. (2004) in health care market, retail banking (Lewis \& Soureli, 2006), automobile repair setting (Yieh et al., 2007), airline industry (Hussain et al., 2015) and a number of various service settings. By enhancing service quality, companies can influence customer loyalty and retention (Choi et al., 2004). Evidence in support of significant impact of service quality on customer loyalty comes from a wide variety of business settings (Gounaris et al., 2010; Mandhachitara \& Poolthong, 2011; Quach et al., 2016). On the basis of aforementioned empirical findings, the following hypotheses are proposed:

$\mathrm{H} 1$ : Service quality is positively associated with customer satisfaction $\mathrm{H} 2$ : Service quality is directly related to customer loyalty.

\subsection{Customer satisfaction}

Customer satisfaction can be defined as "the consumer's response to the evaluation of the perceived discrepancy between prior expectations (or some other norm of performance) and the actual performance of the product as perceived after its consumption" (Tse \& Wilton, 1988, pp. 204), whereas confirmation and positive disconfirmation of expectations will likely result in satisfaction and negative disconfirmation leads to dissatisfaction. According to Anderson et al. (1994) delivery of quality goods and services results in customer satisfaction which in turn positively affects company's profitability. 
Rajić T. et al.: The Antecedents of SMEs' Customer Loyalty: Examining the role...

The aforementioned authors further claim that customer satisfaction reduces price elasticity, leads to more frequent purchases and purchases in greater volume and results in the enhancement of overall reputation of a company. Examining the effects of service quality and customer satisfaction on customers' purchase intentions in several service settings (entertainment services, long distance telephone services, spectator sports, health care, fast food services) Brady et al. (2002) provide evidence of more significant influence of customer satisfaction on purchase intentions. Positive impact of satisfaction on customer loyalty was also supported in a number of service settings, including retail banking (Lewis \& Soureli, 2006), automobile service and repair centers (Yieh et al., 2007), e-retailing (Gounaris et al., 2010), provision of internet services (Quach et al., 2016). Accordingly, the following hypothesis is proposed:

H3: Customer satisfaction has a positive effect on customer loyalty.

\subsection{Trust}

The construct of trust has been regarded as a basis of any human interaction and a key building block of relationship commitment (Guenzi et al., 2009), i.e. an enduring desire to maintain an important relationship. However, in comparison to service quality and customer satisfaction, the construct and its relative impact on consumer behavior have gained less attention in scholarly work. Morgan and Hunt (1994, pp. 23) define trust as "a willingness to rely on an exchange partner in whom one has confidence" and further assert that having trust in relational exchange partner would imply that one would be committed to maintaining that relationship. Trust in exchange partner's reliability and integrity is particularly important in service industries, all the more so the richer services are in credence and experience attributes (Berry, 1995). According to Moliner (2009) trust encompasses two components, honesty and benevolence, whereas honesty refers to the belief that the company as an exchange partner will keep its word and benevolence is a belief that the company is interested in customer's well-being. Communication from another party which is relevant, timely and reliable is the main precursor of trust (Morgan \& Hunt, 1994) whereas trustworthy relations with a company further evolve into customers' intentions to stay in a relationship and willingness to invest into the relationship (Nusair et al., 2013). Results of a study conducted in a health care setting in Spain indicate positive effects of both perceived service quality and patient satisfaction on patient trust and its significant contribution to the development of patients' commitment and loyalty (Moliner, 2009). Similar findings are reported also by Chiou and Droge (2006) whose study in premium cosmetics market indicate significant impact of interactive service quality on trust and its impact on customer intention to use the same brand again. Pivotal role of trust in the development of customer 
Rajić T. et al.: The Antecedents of SMEs' Customer Loyalty: Examining the role...

loyalty was also empirically supported in the contexts of traditional and eretailing (Harris \& Goode, 2004; Evanschitzky et al., 2012). Accordingly, the following hypotheses are proposed:

$\mathrm{H} 4$ : Service quality has a positive effect on trust;

H5: Customer satisfaction has a positive effect on trust;

H6: Trust has a positive effect on customer loyalty.

Conceptual model comprising hypothesized relationships is presented in Figure 1.

Figure 1. Conceptual model

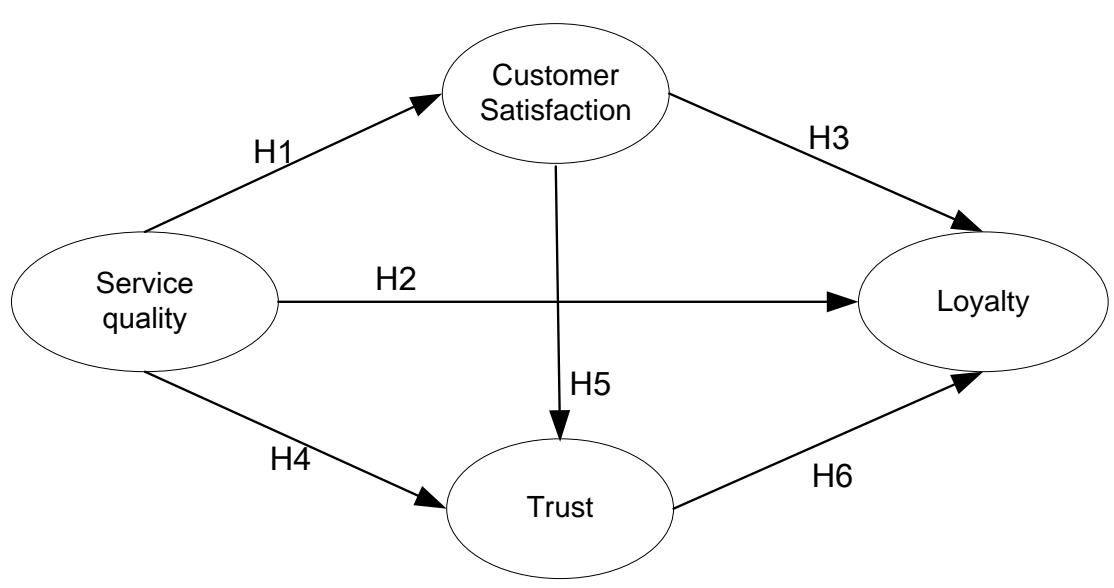

\section{Research methodology}

Hypothesized relationships have been examined on a convenience sample of grocery retailing customers in Serbia. As this investigation was the part of a larger study, only responses relating to small and medium-sized retailers were taken into examination of proposed hypotheses, which yielded 286 usable responses, out of 568 completely fulfilled questionnaires. Personal interviewing, by means of structured questionnaire, was employed in the process of data collection. Respondents were first presented with a succinct explanation of the study's aim, after which they were asked to rate the retailer 
Rajić T. et al.: The Antecedents of SMEs' Customer Loyalty: Examining the role...

at whose outlets they make majority of their grocery shopping. Respondents were asked to fulfil five sections of a questionnaire. First section included items referring to customer's perceptions of service quality, whereas the following sections comprised items related to customer satisfaction, trust and customer loyalty intentions. Final section of the questionnaire included demographic items.

Group interviews with retail customers generated a pool of service qualityrelated items. As described previously, the study was an attempt to reconcile two service quality perspectives. Therefore, SERVQUAL scale was first discussed with respondents. In line with Choi et al.'s (2004) claims of the necessity of formulating service quality items taking into account service industry which provides the context of the study, as well as arguments relating to the inappropriateness of gap approach which underlies the SERVQUAL scale, a pool of performance-only items addressing core and interactive dimensions of retail service quality was generated. Initial pool was further subtracted, as a result of iterative procedure of exploratory factor analysis (EFA). Items retained for the analysis of structural relations are presented in the Appendix.

The construct of customer satisfaction was measured by three items used in previous studies (Chiou \& Droge, 2006; Lewis \& Soureli, 2006) and adapted to the context of retailing. Respondents were asked to rate the following items: (1) This retailer meets my needs, (2) I am satisfied with the purchases made at this retailer's, (3) I am very satisfied with the purchases made at this retailer's. Customer loyalty was measured on a 3 -item scale, adapted from previous studies (Choi et al., 2004; Lewis \& Soureli, 2006). Respondents were asked to indicate the likelihood of recommending the retailer to a friend, saying positive things about the retailer and probability of making most of their future grocery purchases from the same retailer. The construct of trust was measured on a 3-item semantic differential scale. In line with Choi and Droge's (2006) conceptualization of trust, respondents were asked to rate the retailer on the following traits: reliable/unreliable, professional/unprofessional, responsible/irresponsible. With the exception of trust, all constructs were measured on 7-point Likert-type scales ranging from 1-strongly disagree to 7strongly agree.

In order to identify underlying dimensions of service quality, initial pool of quality-related items was subjected to exploratory factor analysis (EFA). In the following stage, relationships among the study's constructs were examined by means of structural equation modelling (SEM), using maximum likelihood as the method of parameter estimation. Estimation of structural relationships adhered to two-step procedure proposed by Anderson and Gerbing (1988), implying estimation of measurement model, followed by the examination of 
Rajić T. et al.: The Antecedents of SMEs' Customer Loyalty: Examining the role...

structural relations. Data analysis was performed using SPSS 18 and LISREL 8.80 .

\section{Results}

In order to condense larger number of quality-related items into smaller number of factors initial pool of items was subjected to principal component analysis (PCA) with varimax rotation. Suitability of data for factor analysis was examined on the basis of Kaiser-Meyer-Olkin measure of sampling adequacy (KMO) and Bartlett's Test of Sphericity, whereas KMO measure of .883 and significant value of Bartlett's test $\left.\chi_{45}^{2}=1145.451, p=.000\right)$ indicated the existence of significant correlations among the items and therefore allowed for factor analysis to be performed. Factors were extracted on the basis of eigenvalue higher than one, whereas factor loadings lower than .40 were suppressed and items with high cross-loadings were excluded from further analysis. Iterative procedure resulted in two factors, named interactive and core service quality, which accounted for $58,6 \%$ of variance in the sample. Rotated component matrix is presented in the Appendix. Reliability of the items explained by the factors was examined in the following stage, to ensure that the study's findings have the ability to provide consistent results in repeated instances. Cronbach's alpha coefficients of interactive and core service quality of .886 and .795 respectively, being higher than the lower threshold of .70 , indicated acceptable internal consistency of service quality dimensions. Prior to the examination of conceptual model, partial disaggregation of service quality items was performed, following recommendations of Dabholkar et al. (1996).

Confirmatory factor analysis was performed to examine whether relationships between measurement items and their respective constructs were supported. Although statistically significant and therefore poor chi-square fit statistic suggested a poor fit of the model to the data $\left(\chi^{2}{ }_{65}=195,291, p<.001\right)$, as was expected due to a sample size larger than 200 (Cudeck \& Henly, 1991), other absolute and relative fit indices suggested a good model fit, as depicted in Table 1.

Table 1. Measurement model fit

\begin{tabular}{llllllll}
\hline \hline Fit indices & GFI & AGFI & RMSEA & SRMR & CFI & NFI & NNFI \\
\hline $\begin{array}{l}\text { Measurement } \\
\text { model }\end{array}$ & 0.91 & 0.86 & 0.08 & 0.06 & 0.96 & 0,94 & 0.95 \\
\hline $\begin{array}{l}\text { Recommended } \\
\text { value }\end{array}$ & $\geq 0.90$ & $\geq 0.90$ & $\leq 0.80$ & $\leq 0.80$ & $\geq 0.90$ & $\geq 0.90$ & $\geq 0.90$ \\
\hline \hline
\end{tabular}


Rajić T. et al.: The Antecedents of SMEs' Customer Loyalty: Examining the role...

Note: *Goodness of fit index (GFI); Adjusted goodness of fit index (AGFI); Normed fit index (NFI); Non-normed fit index (NNFI); Comparative fit index (CFI); Standardized root mean square residual (SRMR); Root mean square error of approximation (RMSEA)

Source: authors'

Due to acceptable fit of the proposed model, the analysis proceeded with the assessment of construct validity, which relates to the degree to which a set of measured variables appropriately represent the latent construct they are designed to measure (Hair et al., 2010). Construct validity implies the assessment of convergent and discriminant validity. Evidence in support of convergent validity is provided by average variance extracted (AVE), i.e. a measure of convergence among a set of items representing the same construct, which is higher than 0.50 (Bagozzi, Yi, 1991). All constructs fulfill this condition. Statistically significant factor loadings higher than 0.50 , as presented in Table 2, also indicate convergent validity of the constructs. Internal consistency (Cronbach alpha $>0.70)$ and composite reliability $(\rho>0.70)$ coefficients also indirectly provide evidence in support of convergent validity of the constructs.

Table 2. Assessment of convergent validity

\begin{tabular}{lllll}
\hline \hline Constructs & $\begin{array}{l}\text { St. factor } \\
\text { loadings }\end{array}$ & t-values & $\begin{array}{l}\text { Cronbach } \\
\text { alpha }\end{array}$ & $\begin{array}{l}\text { Composite } \\
\text { reliability }\end{array}$ \\
\hline $\begin{array}{l}\text { Interactive } \\
\text { quality }\end{array}$ & $0.82-0.87$ & $16.51-18.18$ & 0.88 & 0.88 \\
\hline Core quality & $0.68-0.90$ & $13.11-19.08$ & 0.78 & 0.79 \\
\hline $\begin{array}{l}\text { Customer } \\
\text { satisfaction }\end{array}$ & $0.88-0.90$ & $21.00-21.98$ & 0.92 & 0.92 \\
\hline Trust & $0.81-0.89$ & $17.03-17.93$ & 0.88 & 0.88 \\
\hline Customer loyalty & $0.76-0.94$ & $17.74-27.90$ & 0.91 & 0.91 \\
\hline \hline
\end{tabular}

Source: authors'

Discriminant validity refers to the degree to which two conceptually similar constructs are different (Hair et al., 2010). Discriminant validity of the constructs was examined by comparing squared correlations among the constructs with AVE values of each investigated construct, to determine whether AVE values exceed squared intercorrelations among the constructs. Matrix of squared correlations together with AVEs on the diagonal is presented in Table 3.

Acceptable fit of measurement model and supported validity of the constructs allowed for the examination of relationships among the constructs. Conceptual model was examined my means of SEM, which is suitable as it allows simultaneous examination of multiple dependence relationships among the constructs. In spite of statistically significant chi-square statistic 
Rajić T. et al.: The Antecedents of SMEs' Customer Loyalty: Examining the role...

$\left.\chi_{66}^{2}=196,452, \mathrm{p}<.001\right)$, other fit indices indicate that the model was good fit to the data. Indices of structural model fit are presented in Table 4.

Table 3. Assessment of discriminant validity

\begin{tabular}{llllll}
\hline \hline & $\begin{array}{l}\text { Interactive } \\
\text { quality }\end{array}$ & $\begin{array}{l}\text { Core } \\
\text { quality }\end{array}$ & $\begin{array}{l}\text { Customer } \\
\text { satisfaction }\end{array}$ & Trust & $\begin{array}{l}\text { Customer } \\
\text { loyalty }\end{array}$ \\
$\begin{array}{l}\text { Interactive } \\
\text { quality }\end{array}$ & $\mathbf{0 . 7 2}$ & & & & \\
$\begin{array}{l}\text { Core } \\
\text { quality }\end{array}$ & 0.52 & $\mathbf{0 . 6 7}$ & & & \\
$\begin{array}{l}\text { Customer } \\
\text { satisfaction }\end{array}$ & 0.43 & 0.43 & $\mathbf{0 . 7 9}$ & & \\
$\begin{array}{l}\text { Trust } \\
\text { Customer loyalty }\end{array}$ & 0.40 & 0.37 & 0.62 & $\mathbf{0 . 7 2}$ & \\
\hline \hline
\end{tabular}

Source: authors'

Table 4. Structural model fit

\begin{tabular}{|c|c|c|c|c|c|c|c|}
\hline Fit indices* & GFI & AGFI & RMSEA & SRMR & CFI & $\mathrm{NFI}$ & NNFI \\
\hline $\begin{array}{l}\text { Measurement } \\
\text { model }\end{array}$ & 0.91 & 0.86 & 0.08 & 0.06 & 0.96 & 0,94 & 0.94 \\
\hline $\begin{array}{l}\text { Recommended } \\
\text { value }\end{array}$ & $\geq 0.90$ & $\geq 0.90$ & $\leq 0.80$ & $\leq 0.80$ & $\geq 0.90$ & $\geq 0.90$ & $\geq 0.90$ \\
\hline \multicolumn{4}{|c|}{ Hypothesis testing } & $\begin{array}{l}\text { St. } \\
\text { estimates }\end{array}$ & t-value & \multicolumn{2}{|c|}{ Results } \\
\hline \multicolumn{4}{|c|}{$\begin{array}{l}\text { H1a: Interactive quality } \rightarrow \text { Customer } \\
\text { satisfaction }\end{array}$} & 0.38 & 4.44 & \multicolumn{2}{|c|}{ Supported } \\
\hline \multicolumn{4}{|c|}{ H1b: Core quality $\rightarrow$ Customer satisfaction } & 0.38 & \multirow{2}{*}{4.19} & \multirow{2}{*}{\multicolumn{2}{|c|}{$\begin{array}{l}\text { Supported } \\
\text { Not } \\
\text { supported }\end{array}$}} \\
\hline \multicolumn{4}{|c|}{ H2a: Interactive quality $\rightarrow$ Loyalty } & 0.04 & & & \\
\hline \multicolumn{4}{|c|}{ H2b: Core quality $\rightarrow$ Loyalty } & 0.09 & 1.60 & \multicolumn{2}{|c|}{$\begin{array}{l}\text { Not } \\
\text { supported }\end{array}$} \\
\hline \multicolumn{4}{|c|}{ H3: Customer satisfaction $\rightarrow$ Loyalty } & 0.69 & 9.95 & \multicolumn{2}{|c|}{ Supported } \\
\hline \multicolumn{4}{|c|}{$\mathrm{H} 4$ : Interactive service quality $\rightarrow$ Trust } & 0.21 & 3.17 & \multicolumn{2}{|c|}{ Supported } \\
\hline \multicolumn{4}{|c|}{ H5: Customer satisfaction $\rightarrow$ Trust } & 0.65 & 9.52 & \multicolumn{2}{|c|}{ Supported } \\
\hline \multicolumn{2}{|c|}{ H6: Trust $\rightarrow$ Loyalty } & & & 0.18 & 2.82 & \multicolumn{2}{|c|}{ Supported } \\
\hline \multicolumn{4}{|c|}{ H7: Interactive quality $\rightarrow$ Core quality } & 0.72 & 12.18 & \multicolumn{2}{|c|}{ Supported } \\
\hline
\end{tabular}

Note: *Goodness of fit index (GFI); Adjusted goodness of fit index (AGFI); Normed fit index (NFI); Non-normed fit index (NNFI); Comparative fit index (CFI); Standardized root mean square residual (SRMR); Root mean square error of approximation (RMSEA)

Source: authors'

Due to acceptable fit of the model, structural relations were examined subsequently. Standardized estimates of structural relationships are displayed in Figure 2. 
Rajić T. et al.: The Antecedents of SMEs' Customer Loyalty: Examining the role...

As indicated by Hypothesis 1, results of the study provide evidence in support of significant impact of both service quality dimensions on customer satisfaction. Contrary to what was predicted in Hypothesis 2, service quality, i.e. interactive nor core quality, did not exert significant impact on customer loyalty $\left(\gamma_{31}=0.04, t=0.77 ; \beta_{32}=0.09, t=1.60\right)$. As predicted in Hypothesis 3 , customer satisfaction had a significant positive impact on customer loyalty $\left(\beta_{53}=0.69, t=9.95\right)$. The results also showed that trust was directly influenced by service quality, i.e. interactive service quality exerted significant impact on trust $\left(\mathrm{Y}_{41}=0.21, \mathrm{t}=3.17\right)$, whereas the impact of core quality on trust was not examined, as literature review indicates the relevance of service personnel behavior for the development of trustful relationships among exchange partners. Findings of this study also indicate significant impact of customer satisfaction on trust $\left(\beta_{43}=0.65, t=9.52\right)$. Therefore, $\mathrm{H} 5$ was also supported, as well as Hypothesis 6 , implying significant influence of trust on customer loyalty $\left(\beta_{54}=0.18, t=2.82\right)$. Generally, findings of this study provide strong evidence in support of proposed conceptual model, with the exception of direct influence of service quality on customer loyalty. Strong explanatory power of the model should be also acknowledged. Proposed constructs explain $87 \%$ of the variance in customer loyalty, which indicates adequate representation of customer loyalty determinants.

Figure 2. Standardized estimates of structural relationships

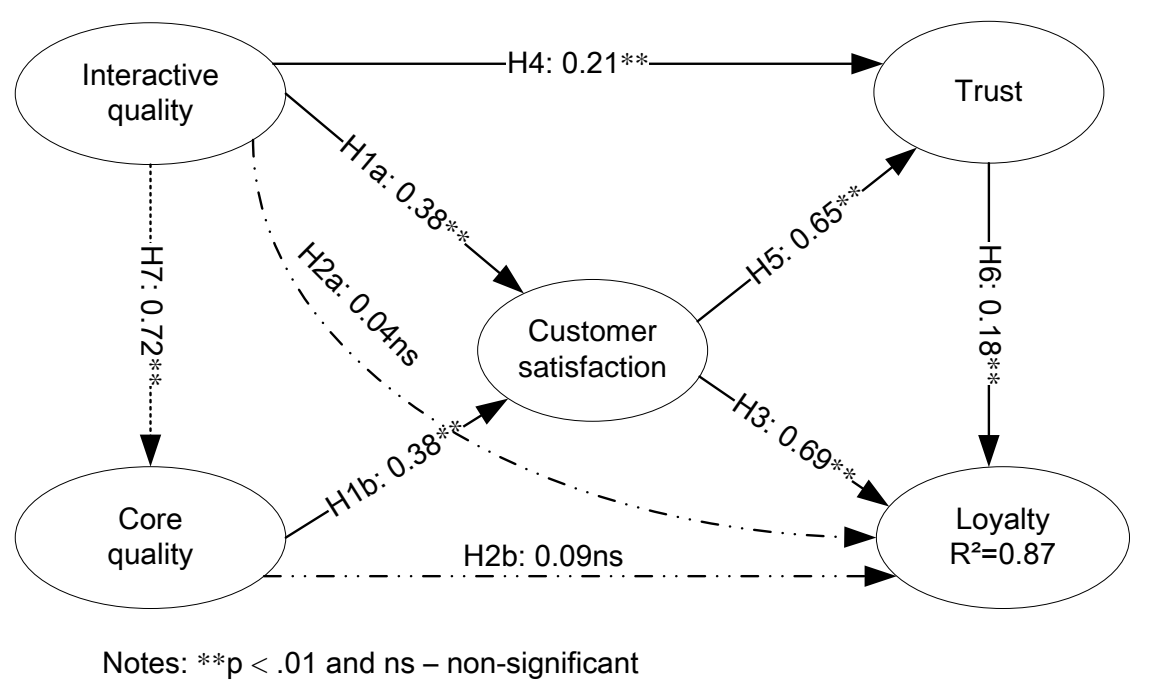


Rajić T. et al.: The Antecedents of SMEs' Customer Loyalty: Examining the role...

\section{Discussion}

The main thrust of this study was to propose an integrative model of customer loyalty, based on established relationships among key determinants of customer loyalty and enhance previous conceptualizations by incorporating the construct of trust, and empirically examine the model in the context of Serbian SMEs. As such, intended contributions of this study to current understanding of consumer behavior are threefold. First, special attention was paid to the selection of SMEs' customers and gaining more profound insights into key determinants of customer loyalty in this sector, which is expected to be the driving force of economic growth and development. Second, majority of previous studies on customer loyalty have focused on service quality and customer satisfaction and their interrelatedness in the formation of customer loyalty, whereas unequal attention was paid to the construct of trust, although building trustful relationships has already been acknowledged as an investment with a long-term payoff. Third, vast majority of previous research on the determinants of customer loyalty has been performed in the context of US and Western Europe, whereas emerging economies have to a great extent been neglected. Therefore, this study which examined service quality, satisfaction and trust as the determinants of customer loyalty in the context of SMEs of an emerging economy contributes to the extension of existing marketing knowledge.

As for the first hypothesis, results of the study indicate significant direct impact of both interactive and core quality on customer satisfaction. Therefore, both $\mathrm{H} 1 \mathrm{a}$ and $\mathrm{H} 1 \mathrm{~b}$ are supported by empirical findings. We additionally tested hypothesis $\mathrm{H} 7$, implying the direct effect of interactive quality on core quality. According to this study's findings, customers' perceptions of core quality are influenced by interactive quality, i.e. employees' courtesy, willingness to do more than expected in order to fulfill customers' needs, trustworthiness of employees and their willingness to refund the purchase price, when purchased articles are unsatisfactory, etc. These findings bear special managerial relevance for small and medium-sized retailers, which are not in a position to compete with large retailing enterprises in terms of depth and width of assortment. Nevertheless, competitive differentiation of small and mediumsized retailers may be founded on courtesy and responsiveness of front-line personnel. Contrary to what was proposed by the second hypothesis, service quality, comprising interactive and core quality, did not emerge as a significant direct determinant of customer loyalty. However, by no means does it imply that the delivery of quality services is not important for the development of customer loyalty. Both interactive and core quality significantly contribute to customer loyalty, as their impact is mediated via customer satisfaction and trust, whereas in terms of standardized total effects on loyalty, 0.67 and 0.39 
Rajić T. et al.: The Antecedents of SMEs' Customer Loyalty: Examining the role...

respectively, interactive quality emerged as a more influential determinant of customer loyalty. In this regard, findings of the study are in compliance with Parasuraman et al.'s (1985) assertion of greater relevance of process-related aspects of service quality. Both interactive service quality and customer satisfaction also emerged as direct determinants of trust $(\mathrm{H} 4, \mathrm{H} 5)$, thus empirically supporting Moliner's (2009) findings of the relevance of both quality and satisfaction for the development of customer trust in service providers. This study's findings also indicate significant direct influence of both customer satisfaction and trust on loyalty, thus providing support for hypotheses $\mathrm{H} 3$ and $\mathrm{H} 6$. Standardized coefficients of direct satisfaction-loyalty and trust-loyalty relationships reached values of 0.69 and 0.18 , respectively. In addition to direct association between satisfaction and loyalty, the impact of customer satisfaction on loyalty is also mediated via trust. Its standardized total effect on loyalty reached a value of 0.81 and customer satisfaction emerged as the most significant determinant of customer loyalty. Less significant impact of trust, in comparison to customer satisfaction, on the development of loyalty might be attributed to the nature of retailing services. According to Parasuraman et al.'s (1985) conceptualization, retailing services abound with search, in comparison to experience and credence attributes and the nature of these services diminishes the importance of trust and interpersonal factors in the development of loyalty, as users do not depend on service providers for information, expertise and interpersonal qualities he displays (Moorman et al., 1993).

Findings of this study bear both theoretical and managerial relevance. From the managerial viewpoint, results of the study indicate the importance of more thorough examination of customer satisfaction, as the most important driver of customer loyalty, and its periodic assessment with the aim of taking necessary corrective actions, when needed. Due attention should be also paid to service quality, as it emerged as a significant determinant of satisfaction. Future studies should focus on more profound examination of service quality attributes with the aim of devising service quality instruments which are suitable for measurements of service quality in specific service settings.

In spite of its contributions, this study is not bereft of limitations either. The main limitation of the study is the size and scope of the sample. Future studies should focus on more randomized samples and include customers of diverse industries, in order to generalize research findings. Previous studies indicate significant correlation between corporate social responsibility (CSR) and customer satisfaction and loyalty (Marić et al., 2015). Therefore, examination of more comprehensive models, including CSR as a determinant of loyalty, would be an avenue worthy of further study. 
Rajić T. et al.: The Antecedents of SMEs' Customer Loyalty: Examining the role...

\section{Conclusion}

The overarching goal of this study was to examine the determinants of SMEs' customer loyalty. Proposed and empirically examined model of customer loyalty builds upon previously established relationships among key determinants of customer loyalty and enhances previous conceptualizations by incorporating the construct of trust. Results of the study indicate direct relatedness of customer satisfaction and trust to customer loyalty, whereas the effects of service quality dimensions on loyalty are mediated via satisfaction and trust. Taking into account indirect relatedness of interactive and core quality to customer loyalty, by no means the findings of this study indicate irrelevance of service quality dimensions for building customer loyalty. In terms of total effect, customer satisfaction emerged as the most significant determinant of loyalty, followed by interactive, core quality and trust. Findings of this study point to the necessity of more thorough examination of service quality dimensions and periodical assessment of customers' perceptions of service quality, due to its significant effect on customer satisfaction and its contribution to the development of trustworthy relationships between customers and enterprises, as well as building loyal customer base. Enterprises which pay attention to the identification of service quality attributes and most salient quality dimensions, from the perspective of their target customers, and compare themselves to competitors, are in a position to identify their strengths and weaknesses and take appropriate corrective actions accordingly.

However, due to the scope of this study, one should be circumspect in generalizing this study's findings. Therefore, future research calls for more representative samples, as well as examination of interrelatedness among the determinants of customer loyalty and their relative impact on loyalty taking into account diverse service and manufacturing industries.

\section{References}

Anderson, E.W., Fornell, C., \& Lehmann, D.R. (1994). Customer Satisfaction, Market Share, and Profitability: Findings From Sweden. Journal of Marketing, 58, 53-66.

Bagozzi, R.P., \& Yi, Y. (1991). Multitrait-Multimethod Matrices in Consumer Research. Journal of Consumer Research,17(4), 426. doi:10.1086/208568

Berry, L.L. (1995). Relationship Marketing of Services: Growing Interest, Emerging Perspectives. Journal of the Academy of Marketing Science, 23(4), 236-245. doi:10.1177/009207039502300402

Brady, M.K., Cronin, J.J., \& Brand, R.R. (2002). Performance-only measurement of service quality: A replication and extension. Journal of Business Research, 55, 17-31. 
Rajić T. et al.: The Antecedents of SMEs' Customer Loyalty: Examining the role...

Chiou, J.-., \& Droge, C. (2006). Service Quality, Trust, Specific Asset Investment, and Expertise: Direct and Indirect Effects in a Satisfaction-Loyalty Framework. Journal of the Academy of Marketing Science, 34(4), 613-627. doi:10.1177/0092070306286934

Choi, K.S., Cho, W.H., Lee, S., Lee, H., \& Kim, C. (2004). The relationships among quality, value, satisfaction and behavioral intention in health care provider choice: A South Korean study. Journal of Business Research, 57, 913-921.

Cudeck, R., \& Henly, S.J. (1991). Model selection in covariance structures analysis and the "problem" of sample size: A clarification. Psychol Bull, 109(3), 512-9. pmid:2062982

Dabholkar, P.A., Thorpe, D.I., \& Rentz, J.O. (1996). A measure of service quality for retail stores: Scale development and validation. Journal of the Academy of Marketing Science, 24(1), 3-16. doi:10.1007/BF02893933

Dick, A.S., \& Basu, K. (1994). Customer Loyalty: Toward an Integrated Conceptual Framework. Journal of the Academy of Marketing Science, 22(2), 99-113. doi:10.1177/0092070394222001

Durvasula, S., Lysonski, S., \& Mehta, S.C. (2005). Service Encounters: The Missing Link Between Service Quality Perceptions And Satisfaction. The Journal of Applied Business Research, 21(3), 15-26.

-Eurostat. (2011). Key figures on European business, with a special feature on SMEs. Luxembourg-Belgium: Aleksandra Stawińska.

Evanschitzky, H., Ramaseshan, B., Woisetschläger, D.M., Richelsen, V., Blut, M., \& Backhaus, C. (2012). Consequences of customer loyalty to the loyalty program and to the company. Journal of the Academy of Marketing Science, 40(5), 625638.

Gounaris, S., Dimitriadis, S., \& Stathakopoulos, V. (2010). An examination of the effects of service quality and satisfaction on customers' behavioral intentions in e-shopping. Journal of Services Marketing, 24(2), 142-156.

Greenland, S., Coshall, J., \& Combe, I. (2006). Evaluating service quality and consumer satisfaction in emerging markets. International Journal of Consumer Studies, 30(6), 582-590.

Grönroos, C. (2000). Service Management and Marketing: A Customer Relationship Management Approach, 2nd ed.. Chichester, England: John Wiley \& Sons, Ltd..

Hair, J.F., Black, W.C., Babin, B.J., \& Anderson, R.E. (2010). Multivariate Data Analysis: A Global Perspective, Upper Saddle River, 7th ed.. New Jersey: Pearson Prentice Hall.

Harris, L.C., \& Goode, M.M.H. (2004). The four levels of loyalty and the pivotal role of trust: A study of online service dynamics. Journal of Retailing, 80, 139-158.

Hussain, R., Nasser, A.A., \& Hussain, Y.K. (2015). Service quality and customer satisfaction of a UAE-based airline: An empirical investigation. Journal of Air Transport Management, 42, 167-175.

Lewis, B.R., \& Soureli, M. (2006). The antecedents of consumer loyalty in retail banking. Journal of Consumer Behaviour, 5, 15-31.

Lovreta, S. (2008). Strategija i politika razvoja trgovine Republike Srbije. Beograd, Srbija: Naučno-istraživački centar Ekonomskog fakulteta (NICEF).

Mamula, T., \& Popović-Pantić, S. (2015). Relationship between Innovativeness and Strategic Planning: Empirical research. Industrija, 43(4), 47-65. doi:10.5937/industrija43-8718 
Rajić T. et al.: The Antecedents of SMEs' Customer Loyalty: Examining the role...

Mandhachitara, R., \& Poolthong, Y. (2011). A model of customer loyalty and corporate social responsibility. Journal of Services Marketing, 25(2), 122-133.

Marić, T., Nikolić, I., Marić, R., \& Dželetović, M. (2015). Social Responsibility in ECommerce: Reflection on Customer's Satisfaction and Loyalty in Internet Promotion of Tourist Services. Industrija, 43(2), 73-88. doi:10.5937/industrija437902

McDougall, G.H.G., \& Levesque, T. (2000). Customer satisfaction with services: Putting perceived value into the equation. Journal of Services Marketing, 14(5), 392-410.

Moliner, M.A. (2009). Loyalty, perceived value and relationship quality in healthcare services. Journal of Service Management, 20(1), 76-97.

Moorman, C., Deshpande, R., \& Zaltman, G. (1993). Factors Affecting Trust in Market Research Relationships.Journal of Marketing, 57, 81-101.

Morgan, R.M., \& Hunt, S.D. (1994). The Commitment-Trust Theory of Relationship Marketing. Journal of Marketing,58, 20-38.

Nusair, K.K., Bilgiha, A., Okumus, F., \& Cobanoglu, C. (2013). Generation Y travelers' commitment to online social network websites. Tourism Management, 35, 13-22.

Parasuraman, A., Zeithaml, V.A., \& Berry, L.L. (1985). A Conceptual Model of Service Quality and Its Implications for Future Research. Journal of Marketing, 49, 4150.

Parasuraman, A., Zeithaml, V., \& Berry, L. (1988). SERVQUAL: A Multiple-Item Scale for Measuring Consumer Perceptions of Service Quality. Journal of Retailing, 64, $12-40$.

Quach, T.N., Thaichon, P., \& Jebarajakirthy, C. (2016). Internet service providers' service quality and its effect on customer loyalty of different usage patterns. Journal of Retailing and Consumer Services, 29, 104-113.

Reichheld, F.F., \& Sasser, E.W. (1990). Zero Defections: Quality Comes to Services. Harvard Business Review, 68(5), 105-111.

Reichheld, F.F. (1993). Loyaty-based management. Harvard Business Review, 71(2), 64-73.

Reichheld, F.F. (2003). The One Number You Need to Grow. Harvard Business Review, 81(12), 46-54.

-Republički zavod za statistiku. (2014). Strukturne poslovne statistike. Godišnji pokazatelji poslovanja preduzeća, po klasama zaposlenih lica. Retrieved from http://webrzs.stat.gov.rs/WebSite/public/ReportView.aspx

Tse, D.K., \& Wilton, P.C. (1988). Models of Consumer Satisfaction Formation: An Extension. Journal of Marketing Research, 25, 204-212.

-Vlada Republike Srbije. (2014). Strategija za podršku razvoju malih i srednjih preduzeća, preduzetništva i konkurentnosti za period od 2015. do 2020. godine. Retrieved from http://www.rsjp.gov.rs/strateg/50/nac/Strategija\%2012.12.2014\%20Za\%20press. pdf

Yieh, K., Chiao, Y.C., \& Chiu, Y.K. (2007). Understanding the Antecedents to Customer Loyalty by Applying Structural Equation Modeling. Total Quality Management, 18(3), 267-284. 
Rajić T. et al.: The Antecedents of SMEs' Customer Loyalty: Examining the role...

\section{Appendix}

\section{Rotated component matrix}

\begin{tabular}{|c|c|c|c|}
\hline & & \multicolumn{2}{|c|}{ Factor loadings } \\
\hline \multicolumn{4}{|c|}{ Interactive quality } \\
\hline IQ1 & $\begin{array}{l}\text { Employees are affable towards customers if } \\
\text { they want to return or change the purchased } \\
\text { goods }\end{array}$ & .782 & \\
\hline IQ2 & $\begin{array}{l}\text { Employees are sincerely interested in } \\
\text { resolving customers' complaints as soon as } \\
\text { possible }\end{array}$ & .776 & \\
\hline IQ3 & $\begin{array}{l}\text { Employees are always courteous with } \\
\text { customers }\end{array}$ & .735 & \\
\hline IQ4 & $\begin{array}{l}\text { Employees are never too busy to respond to } \\
\text { customer complaints promptly }\end{array}$ & .734 & \\
\hline IQ5 & Employees instill trust into customers & .688 & \\
\hline IQ6 & $\begin{array}{l}\text { Employees have the knowledge to respond to } \\
\text { customers' enquiries }\end{array}$ & .678 & \\
\hline IQ7 & $\begin{array}{l}\text { Employees are willing to do more than they } \\
\text { are asked for in order to help customers }\end{array}$ & .634 & \\
\hline \multicolumn{4}{|c|}{ Core quality } \\
\hline CQ1 & $\begin{array}{l}\text { The layout of the store makes it easy for } \\
\text { customers to move around in the store }\end{array}$ & & .730 \\
\hline CQ2 & $\begin{array}{l}\text { Quantity of goods in stock in retail outlet is } \\
\text { enough to enable smooth supply to customers }\end{array}$ & & .728 \\
\hline CQ3 & $\begin{array}{l}\text { The store layout makes it easy for customers } \\
\text { to find what they need }\end{array}$ & & .725 \\
\hline CQ4 & $\begin{array}{l}\text { The width of the assortment allows the } \\
\text { customers to purchase all necessities at one } \\
\text { place }\end{array}$ & & .695 \\
\hline CQ5 & $\begin{array}{l}\text { The depth of the assortment allows the } \\
\text { customers to fulfill their needs adequately }\end{array}$ & & .601 \\
\hline \multicolumn{2}{|c|}{ Eigenvalues } & 3.961 & 3.069 \\
\hline$\%$ of 1 & ariance & 33.010 & 25.571 \\
\hline \multicolumn{4}{|c|}{ Customers wait a short time in line at the cash register* } \\
\hline \multirow{2}{*}{\multicolumn{4}{|c|}{$\begin{array}{l}\text { The retailer is dedicated to meeting customer needs better than competitors }{ }^{*} \\
\text { The retailer offers various options of deferred payment }{ }^{*}\end{array}$}} \\
\hline & & & \\
\hline $\begin{array}{l}\text { Extracti } \\
\text { Rotatio } \\
\text { *Note: }\end{array}$ & $\begin{array}{l}\text { on Method: Principal Component Analysis } \\
\text { Method: Varimax with Kaiser Normalization } \\
\text { Eliminated on the basis }\end{array}$ & & \\
\hline
\end{tabular}



